\title{
Corrigendum
}

\section{Archaeological evidence of early settlement in Venice: a comment on Ammerman et al. (2017) - CORRIGENDUM}

John Meadows, Nicoletta Martinelli \& Luigi Fozzati

Published by Cambridge University Press, 11 December 2018

Following publication of this article, it was discovered that three of the unexpectedly early radiocarbon dates measured in 1999 from samples obtained by coring underneath St Mark's Basilica had been withdrawn from the literature while the article was in production, and were subsequently replaced by new measurements (published in 2018, 2019 and 2020).

The new dates do not meaningfully affect the authors' model estimate of when settlement began in the Piazza San Marco area, but to avoid any confusion regarding the withdrawal of the original dates, the authors have revised Figure 4 and the online supplementary information accompanying the article.

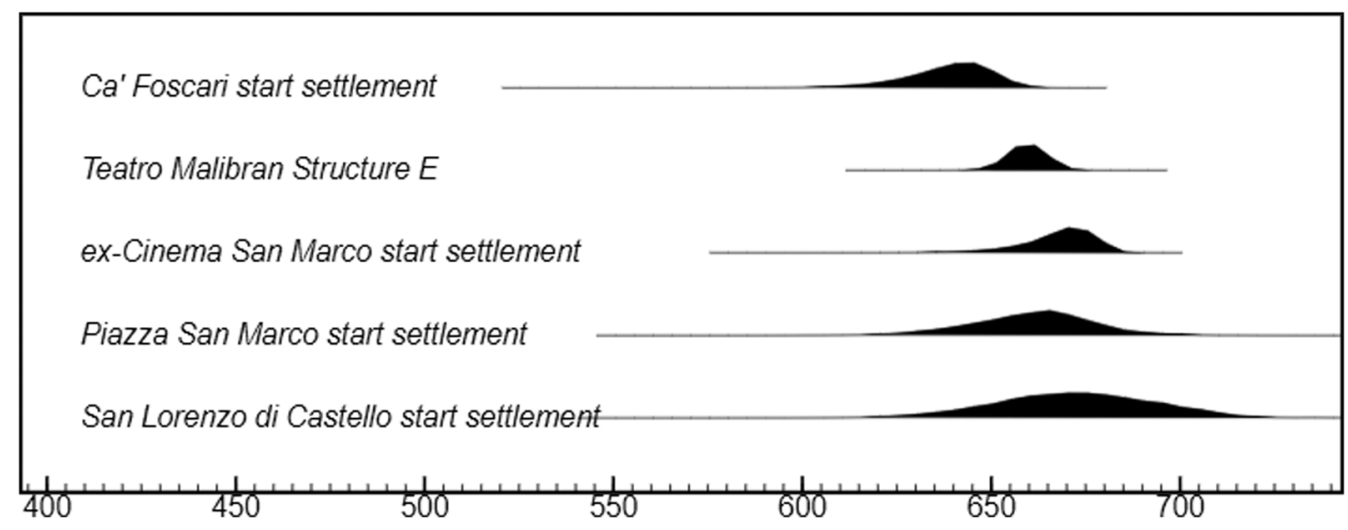

Figure 4. Estimated start of settlement at five locations in central Venice, based on the Bayesian chronological models in Meadows et al. (2012) and the online supplementary information (the Teatro Malibran date is for the cross-matched timber structure shown in Figure 3) (figure by J. Meadows). 


\section{Corrigendum}

\section{References}

Ammerman, A.J., C.L. Pearson, P.J. Kuniholm \& T. BRown. 2019. The cores made beneath the floor of the Basilica di San Marco: first report, in E. Vio (ed.) San Marco, la Basilica di Venezia: Arte, Storia, Conservazione: 59-76. Venice: Marsilio.

Higham, T.F.G., C. Bronk Ramsey, D. Chivall, J. Graystone, D. Baker, E. Henderson \& P. Ditchireld. 2018. Radiocarbon dates from the Oxford AMS system: Archaeometry Datelist
36. Archaeometry 60: 628-40.

https://doi.org/10.1111/arcm.12372

- 2020. Corrigendum. Archaeometry 62: 213. https://doi.org/10.1111/arcm.12506

Meadows, J., N. Martinelli \& L. Fozzati. 2018. Archaeological evidence of early settlement in Venice: a comment on Ammerman et al. (2017). Antiquity 92: 1640-49.

https://doi.org/10.15184/aqy.2018.159 